\title{
Pharmacokinetic Parameter Date Time
}

National Cancer Institute

\section{Source}

National Cancer Institute. Pharmacokinetic Parameter Date Time. NCI Thesaurus. Code C88018.

The date and time of the pharmacokinetic parameter data. 